\title{
Penerapan Developmental State Dalam Sektor Industri Kecil Menengah Di Indonesia: Studi Kasus Kabupaten Bone
}

\author{
(Implementation of Developmental State in Small Medium
}

Industry Sector in Indonesia: Case Study of Bone Regency)

\author{
Andi Amytia Resty Dwiyanti \\ Universitas Teknologi Yogyakarta \\ Email: andiamitya@uty.ac.id \\ M Najeri Al Syahrin \\ Universitas Muhammadiyah Kalimantan \\ Timur Email: najeri.alsyahrin@umkt.ac.id
}

\begin{abstract}
Abstrak
Kegagalan pertumbuhan ekonomi merupakan masalah utama perekonomian jangka panjang suatu negara. Salah satu bentuk upaya pemerintah untuk mengatasi permasalahan tersebut adalah dengan memperbaiki iklim investasi asing melalui sektor industri kecil menengah. Tulisan ini bertujuan untuk mendeskripsikan peran pemerintah Kabupaten Bone dalam proses pembangunan perekonomian sektor industri kecil menengah melalui penerapan strategi developmental state. Perkembangan sektor industri kecil menengah sebagai sektor usaha yang mampu menyerap tenaga kerja serta peluang investasi yang akhirnya akan dapat berpengaruh pada percepatan proses pembangunan di Kabupaten Bone. Metode penelitian yang digunakan adalah metode deskriptif kualitatif dengan telaah dari berbagai data pustaka dan wawancara. Teori yang digunakan adalah developmental state untuk menjelaskan keterkaitan peningkatan ekonomi daerah Kabupaten Bone melalui sektor industri kecil menengah. Penelitian ini menemukan bahwa terdapat intervensi pemerintah Kabupaten Bone dalam proses pembangunan perekonomian yang ditandai dengan kuatnya kontrol pemerintah atas sektor industri kecil menengah dengan meningkatkan iklim investasi asing dan kerja
\end{abstract}


sama internasional. Hal tersebut menjadikan local government sebagai aktor utama dalam menjalankan kebijakan pengembangan ekonomi daerah.

Kata Kunci: Peningkatan Perekonomian, Industri Kecil Menengah, Developmental State, Peran Pemerintah Kabupaten Bone. Investasi Asing.

\begin{abstract}
The failure of economic growth is a major problem of a country's long-term economy. The effort of government to overcome these problems is to improve the athmosfere of foreign investment through the sector of small and medium industries. This paper aims to describe the role of Bone Regency government in the process of developing the economy of small and medium industry sector through the implementation of developmental state strategy. The development of small and medium industrial sector as a business sector that is able to absorb labor and investment opportunities that will eventually affect the acceleration of the development process in Bone District. The research method used is qualitative descriptive method with the study of various bibliography data and interview. The theory used is developmental state to explain the correlation of economic improvement of Bone Regency region through small industry sector. The study found that there is Bone district government intervention in the economic development process which is marked by strong government control over small and medium industry sector by improving foreign investment atmosphere and international cooperation. This makes local government as the main actor in running the policy of regional economic development.
\end{abstract}

Keywords: Economic Growth, Small and Medium Industry, Developmental State, Bone Goverments role, foreign investment.

\section{A. Pendahuluan}

Mencermati peranan

penanaman modal yang cukup signifikan dalam membangun

pe re k o n o mi a n, t id a k lah mengherankan jika kemudian dalam beberapa dekade terakhir ini, negara dan pemerintah berusaha secara optimal agar dapat menjadi tujuan investasi asing. Implikasi atas tumbuh kembangnya penanaman modal yang tinggi akan mempengaruhi proses pembangunan serta pertumbuhan ekonomi. Dalam upaya untuk menumbuhkan 
perekonomian, setiap negara senantiasa berusaha menciptkan iklim dan kondisi yang dapat mendukung serta menciptakan gairah investasi. Iklim investasi yang baik akan menciptakan investasi yang produktif, yang akhirnya akan berpengaruh pada peningkatan kebutuhan lapangan kerja dan perluasan kegiatan usaha dalam sektor lainnya. Investasi selalu memainkan peran dan menjadi katalisator penting dalam peningkatan pertumbuhan ekonomi secara umum. Memperbaiki iklim investasi adalah permasalahan utama dihadapi pemerintah di negara berkembang, termasuk juga di Indonesia (World Bank Report, 2005).

Upaya perbaikan pertumbuhan ekonomi yang dilakukan pemerintah adalah dengan melirik sektor industri kecil menengah (IKM) yang memiliki peran strategis dalam perekonomian nasional. Peran tersebut dapat dilihat dari beberapa hal. Pertama, jumlah IKM yang sangat besar dan menjadi tulang punggung perekonomian nasional. Menurut data Biro Pusat Statistik yang dikutip dari Suci (2017), jumlah IKM di Indonesia pada tahun 2012 sebanyak 56.534.592 unit atau sebesar $99,99 \%$. Sisanya sekitar $0,01 \%$ atau sebesar 4.968 unit adalah usaha berskala besar. Jumlah yang demikian besar tersebut telah menjadikan IKM sebagai pelaku utama dalam ekonomi nasional. Kedua, dalam aneka dimensinya, IKM telah menciptakan lapangan kerja yang luas bagi masyarakat. Menurut angka BPS tahun 2012, total tenaga kerja yang diserap sektor usaha ini sebesar 85 juta orang hingga 107 juta orang tenaga kerja (Suci, 2017). Kegiatan yang dilakukan IKM di wilayah di Kabupaten Bone, berperan besar dalam penyerapan tenaga kerja dan pembentukan produk domestik regional bruto (PDRB). Karena pada dasarnya masyarakat lebih banyak berperan sebagai pelaku usaha baik usaha kecil, menengah, maupun besar (RKPD Kabupaten Bone, 2015).

Peranan yang ketiga dari IKM untuk perekonomian na- sional adalah peranan dalam pembentukan produk domestik bruto (PDB). Jumlah total kalkulasi perhitungan usaha kecil dan menengah adalah $63,54 \%$ dan sisanya $36,46 \%$ adalah usaha besar. Data ini mengkonfirmasi adanya ketimpangan, sebab IKM yang jumlahnya mencapai lebih dari $99,9 \%$ ternyata hanya mengkontribusi atau menerima produk nasional sebesar $63,54 \%$ sementara usaha besar 
yang jumlahnya kurang dari $1 \%$ menerima produk nasional sebesar $36,46 \%$. Ketimpangan ekonomi ini menjadi permasalahan penting pembangunan ekonomi Indonesia di masa mendatang.

Keempat, IKM adalah pelaku ekonomi utama dalam pelayanan kegiatan ekonomi yang berinteraksi langsung dengan masyarakat lapisan bawah. Interaksi tersebut dicapai baik lewat kegiatan produksi di sektor-sektor pertanian, perdagangan dan industri pengolahan maupun dalam kegiatan distribusi. Dimana ujung tombak distribusi yang bersentuhan langsung dengan konsumen akhir adalah pedagang eceran. Kelima, kegiatan ekonomi yang dilakukan oleh IKM mempunyai implikasi langsung dalam kegiatan ekonomi perbankan nasional. Hal ini terbukti hampir $30 \%$ usaha IKM mengunakan modal operasional dari perbankan. Oleh karena itu, IKM memberikan implikasi yang positif bagi tumbuh kembang perbankan nasional secara umum (Suci, 2017).

Dalam hal kemampuan berintegrasi di dalam ekonomi global, sangat jelas juga bahwa sektor yang masih mengalami kesulitan adalah industri kecil dan menengah. Penelitian yang dilakukan oleh Organization for Economic Cooperation and Development (OECD) pada tahun 2007, mengindikasi terdapat empat hambatan terbesar dalam internasionalisasi IKM di beberapa negara terutama negara berkembang yaitu pertama, keterbatasan modal finansial untuk melakukan ekspor. Kedua, kesulitan dalam mengidentifikasi kesempatan bisnis luar negeri dan ketiga, keterbatasan informasi untuk mengalokasikan dan menganalisa pasar. Keempat, yaitu ketidakmampuan dalam melakukan kontak dengan potensial overseas costumer. Perkembangan sektor industri sebagai sektor usaha yang mampu menyerap tenaga kerja dan peluang investasi dapat mempengaruhi percepatan proses pembangunan suatu wilayah khususnya di Kabupaten Bone, dimana sektor industri unggulan akan lebih cepat berkembang dan mendorong tumbuhnya jenis industri baru. IKM berjumlah 62 unit usaha yang tersebar diseluruh wilayah Kabupaten Bone pada umumnya telah membentuk kelompok (sentra) komoditas.

Berdasarkan data PDRB Kabupaten- Bone atas dasar harga berlaku, sektor industri selama kurun waktu 2008-2011 memberikan kontribusi terhadap ekonomi daerah berkisar antara 
$6,85 \%-7,61 \%$. Kontribusi sektor industri ini dari tahun ke tahun sejak 2008 sampai dengan tahun 2011 mengalami penurunan. Pada tahun 2008 kontribusi sektor industri sebesar $7,61 \%$ menurun pada tahun 2011 menjadi $6,85 \%$. Sektor industri ini terdiri dari industri besar, industri, menengah dan kecil. Sektor industri kecil memberikan sumbangan terbesar pada pencapaian kontribusi sektor industri, yaitu antara 3\%-4\%. Perkembangan IKM dari tahun 20082012 bersifat fluktuatif. Rekapitulasi data yang dilakukan penulis sejak tahun 2008 sampai tahun 2015 di Kabupaten Bone, terdapat peningkatan jumlah IKM sebanyak 3.450 unit pada tahun 2010 menjadi 5.609 unit yang kemudian menurun pada tahun 2012 menjadi 3.550 unit. Jumlah IKM terbanyak pada tahun 2010 yaitu sebesar 5.609 unit. Penurunan jumlah IKM terbesar terjadi pada tahun 2009 ke tahun 2010. IKM mampu menyerap tenaga kerja antara $15.000-17.000$ tenaga kerja. Penyerapan tenaga kerja terbesar terjadi pada tahun 2010 yaitu mencapai 17.955 orang. IKM memiliki nilai produksi yang cukup besar. Nilai produksi IKM tertinggi terjadi pada tahun 2010 yaitu sebesar Rp 517.220.943.000 dengan nilai investasi sebesar $\mathrm{Rp}$
126.438.170.000.

Di Kabupaten Bone, data terbaru juga menunjukan terdapat tren yang cenderung stagnan dalam pertumbuhan IKM. Pada tahun 2015, jumlah IKM non BPR/LKM di Kabupaten Bone adalah sebanyak 4570 unit. Dengan perincian sebagai berikut, usaha mikro sebesar 3000 unit, usaha kecil 1500 unit dan usaha menengah 70 unit dengan jumlah total keseluruhan pegawai IKM sebesar 16.000 orang. Pertumbuhan asset IKM pada tahun 2015 berkisar diangka 125 milyar/tahun, sementara untuk pertumbuhan omzet IKM sebesar 900 milyar/tahun (RKPD Kabupaten Bone, 2015). Di sisi lain, pemerintah ditantang untuk menyiapkan dan mengembangkan sarana dan prasarana pemenuhan investasi serta membangun kesiapan dunia usaha pada tingkat wilayah lokal. Kelemahan investasi juga sangat dipengaruhi oleh rendahnya kegiatan pengkajian atau penelitian yang berkaitan dengan pengembangan investasi dan penanaman modal, termasuk belum terwujudnya kerja sama yang sinergis antar satuan kerja perangkat daerah (SKPD), dunia usaha maupun stakeholder terkait lainnya dalam pengembangan investasi dan penanaman modal. 
Berdasarkan dengan permasalahan di atas, dapat dilihat bahwa pengembangan industri kecil dan menengah di Kabupaten Bone masih sangat kurang, dalam pengertian bahwa pertumbuhan IKM tidak stabil dan sering mengalami pasang surut. Sehingga menjadi suatu hal yang menarik untuk diteliti dan didalami lebih lanjut, secara khusus sejauh mana pengembangan dan faktor-faktor apa saja yang mempengaruhi kebijakan pengambangan industri kecil tersebut. Oleh karena itu, agar tercipta suatu bentuk pengembangan yang lebih baik untuk mendukung perkembangan dan pertumbuhan industri kecil di Kabupaten Bone yang tentunya dapat memperkuat ekonomi daerah maka perlu adanya penelitian yang mendalam mengenai kebijakan penerapan developmental state dalam sektor industri kecil dan menengah di Kabupaten Bone.

Tulisan ini bertujuan mendiskripsikan peranan pemerintah Kabupaten Bone dalam proses pembangunan perekonomian dan sektor industri kecil menengah melalui penerapan developmental state. Dalam deskripsi tersebut, penelitian ini menyajikan argumen utama bahwa developmental state merupakan strategi yang sangat diperlukan bagi pemerintah daerah untuk mendukung perkembangan dan pertumbuhan industri kecil di Kabupaten Bone. Urgensi penelitian ini terlihat dalam upaya yang dilakukan dengan menekankan pada strategi developmental state yang cenderung abai dilakukan oleh pemerintah lokal di daerah lain di Indonesia, padahal potensi dari penerapan kebijakan ini sangat besar dalam membantu peningkatan perekonomian nasional.

Pembangunan di bidang IKM menjadi salah satu agenda penting dan prioritas bagi pemerintah Kabupaten Bone. Oleh karena itu, dalam kebijakan umum APBD Kabupaten Bone tahun 2014, mencantumkan pengembangan perekonomian daerah yang terfokus pada program dan kegiatan yang dapat meningkatkan kemandirian dan kesejahteraan masyarakat melalui sektor IKM (RKPD Kabupaten Bone, 2015). Dalam penelitian ini, penulis menggunakan metode deskriptif kualitatif. Metode deskriptif bertujuan untuk menggambarkan bentuk kebijakan yang dilakukan pemerintah daerah untuk meningkatkan ekonomi daerah melalui sektor industri kecil dan menengah. Metode pengumpulan data yang penulis gunakan dalam 
penelitian ini adalah telaah pustaka (library research) yaitu dengan cara mengumpulkan data dari literatur yang berhubungan dengan permasalahan yang akan dibahas, dan kemudian menganalisanya dan indepth-interview dengan Kepala Bidang Industri Dinas Perindustrian Kabupaten Bone untuk memperoleh info yang valid.

\section{B. Konsep Developmental State: Peran Sentral Pemerintah Dalam Kegiatan Ekonomi}

Untuk menjawab permasalahan terkait pengembangan industri kecil di Kabupaten Bone, penulis akan menggunakan konsep developmental state. Gagasan bahwa negara harus memainkan peran sentral dalam pembangunan ekonomi kembali mencuat beberapa tahun terakhir. Secara umum, realitas kegagalan ekonomi telah lama diidentifikasi sebagai justifikasi utama intervensi negara kedalam pasar. Negara atau pemerintah dianggap sebagai agen esensial pembangunan khususnya di negara-negara berkembang. Peran negara dianggap primer dalam melakukan intervensi pasar untuk melindungi ekonomi domestiknyadari dominasi asing. Konsep developmental state di- dasarkan pada peran negara untuk memfasilitasi transisi struktural dari masyarakat primitif/agraria menuju masyarakat modern/manufaktur. Developmental state memainkan peran rekayasa sosial yaitu peran restrukturisasi sistem ekonomi nasional untuk mempromosikan pembangunan industri jangka panjang. Inti utama dari kebijakan ini adalah untuk memelihara sektor industri yang kompetitif dan dinamis. Peran pemerintah yang sangat besar dilakukan dengan peraturan administratif, subsidi, proteksi, hingga peninjauan pasar. Negara secara langsung terlibat dalam pembangunan ekonomi dan memiliki pengaruh yang besar dalam kebijakan ekonomi publik (Kasahara, 2013).

Dalam sebuah studi yang berbeda, Weis dan Thurbon (2016), mengungkapkan bahwa melesat-nya ekonomi Jepang, Taiwan dan Korea Selatan, adalah karena pemerintahnya mengambil pe- ranan proaktif dalam perubahan struktural ekonomi dan peningkatan teknologi khususnya dalam sektor-sektor industri yang memiliki potensi besar untuk mendukung pertumbuhan ekonomi nasional. Pembangunan ekonomi merupakan tujuan utama yang harus dicapai oleh negara. Berbagai hal yang menghambat tercapainya tujuan tersebut berusaha untuk dihindari. 
Pasar diatur melalui instrumen kebijakan yang dirumuskan oleh birokrasi dan elite ekonomi yang merumuskan dan menerapkan kebijakan dalam sektor manufaktur. Sektor manufaktur merupakan sektor dengan tingkat produktivitas yang tinggi. Developmental state juga berkomitmen untuk menyelesaikan konflik ekonomi dan berbagai hambatan dalam proses restrukturisasi sosial. Dengan demikian, negara diharapkan dapat memfasilitasi proses restrukturisasi sehingga tidak berdampak negatif terhadap efisiensi dan produktivitas ekonomi (Kasahara, 2013).

Model developmental state merupakan salah satu model ekonomi dari perspektif merkantilis. Perspektif ini memandang negara sebagai aktor utama yang memiliki tujuan untuk memaksimalkan kekuasaan dengan peningkatan ekonomi. Model pembangunan developmental state menempatkan negara dan pemerintah di posisi terpenting dalam formulasi aktivitas ekonomi. Fokus developmental state dalam liberalisasi ekonomi adalah untuk mengkombinasikan antara orientasi pasar dengan intervensi pemerintah secara efisien dan efektif. Kombinasi ini diharapkan akan membawa stimulasi positif pada percepatan pembangunan ekonomi (Fritz \& Menocal, 2007).

Pembangunan ekonomi tentu membutuhkan peran serta pemerintah yang dapat menciptakan dan mengatur hubungan ekonomi yang akhirnya bisa mampu mendukung kelanjutan industrialisasi (Bolesta, 2007). Dalam strategi pembangunan tersebut, pemerintah akan menaruh perhatian pada peningkatan kerja sama internasional dari industri domestiknya. Hal ini menunjukkan bahwa kebijakan ekonomi dalam pelaksanaannya akan diserahkan kepada sistem birokrasi, melalui proses konsultasi dan kerja sama antara pihak swasta dan pemerintah (Sagenal, 2005). Namun, idealnya konsep developmental state bisa dikatakan efektif adalah ketika sektor swasta dalam ekonomi do- mestik mampu mendapatkan keuntungan maksimal dalam kerjasama internasional (Bolesta, 2007).

Ciri lain dari efektivitas model developmental state adalah rencana pembangunan akan dipertimbangkan secara rasional. Menurut Johnson yang dikutip dari Tun (2011), rasionalitas tersebut berarti bahwa proses pembangunan ekonomi akan dipandu oleh negara dalam arah yang dinginkan sesuai 
dengan kepentingan negara. Disisi lain tentu negara akan memiliki tanggung jawab yang besar atas prestasi dan kegagalan rencana ekonomi dan pembangunan tersebut. Maka dari itu, pemerintah harus mampu untuk bisa memainkan peran sebagai embedded outonomy. Embedded outonomy yaitu otonomi dan otoritas khusus yang diberikan kepada pemerintah dalam kebijakan pembangunan negara dengan melibatkan sistem birokrasi secara efektif ke dalam sektor swasta dan harus bersifat otonom dari kepentingan partikular birokrasi tersebut, sehingga dapat mencapai transformasi industri dan keberhasilan ekonomi jangka panjang.

Penjelasan konsep developmental state di atas tentu akan berhubungan dengan teori pembuatan kebijakan publik. Michael Kraft dan Scott Furlong (2009), mendeskripsikan bahwa dalam teori pembuatan kebijakan publik aktoraktor dan faktor-faktor penting yang berkaitan akan memberikan efek bagi pemerintah saat menetapkan kebijakan (decision making effect). Dimana dalam penelitian ini akan melihat apa saja faktor penting yang mendorong pembuatan ke- bijakan pemerintah daerah dalam melakukan kerja sama baik secara nasional maupun internasional untuk meningkatkan ekonomi daerah melalui pengelolaan Industri Kecil dan Menengah. Faktor pemerintah dan kebijakan yang dihasilkan akan sangat mempengaruhi sinergi dan aktivitas produksi. Pengambilan kebijakan sangat dipengaruhi juga oleh peran kelompok-kelompok kepentingan (aktor) yang berada di sekitar pembuat kebijakan. Thomas Oatley (2013) mengatakan juga bahwa pengambilan kebijakan ekonomi politik internasional selalu terdapat dua aspek utama, yaitu pertama aspek kepentingan (interest) yang muncul dari masyarakat. Dan yang kedua adalah aspek institusi politik, yaitu bagaimana institusi politik dalam sebuah negara menampung, memandu serta mewujudkan kepentingan yang ada di masyarakat menjadi sebuah kebijakan.

Sementara menurut Kuncoro (2007), faktor yang sangat mempengaruhi dalam kebijakan industri kecil adalah visi dari pembuat kebijakan. Visi pembuat kebijakan sangat berperan dalam merumuskan dan menetapkan suatu kebijakan. Bila visi dari pembuat kebijakan adalah untuk mengembangkan ekonomi daerah maka kebijakannya pasti diarahkan maksimal agar bisa mencapai target. Munculnya 
aktor baru pemerintah daerah mempengaruhi pengembangan model hubungan yang bersifat transnasional. Peran sebagai aktor diplomasi tersebut memberi kesempatan kepada pemerintah daerah untuk terlibat langsung dalam investasi dan perdagangan internasional. Dengan demikian, pemerintah daerah, seharusnya bisa berperan aktif dalam memanfaatkan potensi pembangunannya. Secara langsung hal tersebut juga dapat dianggap sebagai sebuah perpanjangan tangan pemerintah pusat dalam memajukan ekonomi masyarakatnya (Fathun, 2016).

Perilaku dan kapasitas untuk melakukan hubungan luar negeri dengan pihak internasional yang dilakukan oleh entitas 'sub-state', pemerintah lokal, regional ataupun pemerintah daerah, dalam rangka kepentingan mereka secara spesifik dalam era globalisasi fenomena ini begitu kuat seiring dengan terbukanya akses dan meningkatnya peran dan pengaruh aktor non negara dalam fora internasional. Daerah memiliki kesempatan untuk mempromosikan perdagangan, investasi, dan berbagai potensi kerjasama dengan pihak-pihak yang berada di luar batas yurisdiksi negara (Wolf \& Stefan, 2009).
C. Kebijakan

Ekonomi

Industri Kecil Menengah di Kabupaten Bone

Secara umum, investasi dapat diartikan sebagai suatu kegiatan yang dilakukan oleh orang pribadi (natural person) maupun badan hukum (furidical person), dalam upaya meningkatkan atau mempertahankan nilai modal- nya, baik yang berbentuk uang tunai (cash money), peralatan (equipment), aset tak bergerak, hak atas kekayaan intelektual, maupun keahlian. Dalam konteks ketentuan Undang-Undang Penanaman Modal, pengertian penanaman modal hanya mencakup penanaman modal secara langsung (Harjono, 2007). Secara empiris kebijakan pemerintah mampu mendorong industri untuk berkembang. Seperti dikemukakan oleh Pangestu dalam Wie (1996), bahwa kebijakan pemerintah telah mendorong secara siginifikan perkembangan industri, seperti kebijakan pemerintah yang dilakukan pada tahun 1930-an yaitu proteksi, subsidi, bantuan teknis dan sistem lisensi telah mendorong berkembangnya berbagai industri, misalnya perakit mobil, tekstil, ban dan rokok untuk memenuhi kebutuhan luar negeri. Menurut Pangabean dalam Infokop (2012), untuk kebijakan pengembangan 
IKM harus mengacu kepada permasalahan yang dihadapi IKM dan pengalaman negara yang sukses membangun IKM.

Industri kecil dan Menengah tergolong batasan usaha kecil dan menengah menurut undang-undang No 20 tahun 2009 tentang usaha mikro, kecil dan didefinisikan sebagai berikut, industri kecil adalah kegiatan ekonomi produktif yang berdiri sendiri, yang dilakukan oleh perorangan atau badan usaha yang bukan merupakan anak perusahaan atau bukan cabang perusahaan yang dimiliki, dikuasai, atau menjadi bagian baik langsung maupun tidak langsung dari usaha menengah atau usaha besar yang memiliki kekayaan bersih lebih dari $\mathrm{Rp} 50.000 .000$ sampai dengan paling banyak Rp500.000.000 tidak termasuk tanah dan bangunan tempat usaha atau memiliki hasil penjualan tahunan lebih dari Rp 300.000.000 sampai dengan paling banyak Rp2.500.000.000. Batasan mengenai skala usaha menurut BPS, yaitu berdasarkan kriteria jumlah tenaga kerja industri kecil yaitu 5 sampai 19 orang dan industri menengah berkisar antara 20 sampai 99 orang (Muhyi \&Zaenal, 2016).

Dengan menjadi salah satu negara dengan populasi terbanyak dan potensi industri yang menjanjikan, Indonesia harus segera melakukan pengembangan. Kaitannya dengan otonomi dan komposisi pemerintahan yang terdiri dari banyak partai serta sistem pemerintahan yang terdesentralisasi membuat pencapaianstabilisasi kepentingan politik Indonesia serta kekuatan negara di berbagai aspek kemudian menjadi tantangan tersendiri. Berbeda dengan Cina yang memiliki otonomi kekuasaan dengan sistem pemerintahan satu partai, sehingga pencapaian stabilisasi politik lebih mudah dilakukan. Keberadaan MP3EI sebagai pilot agency untuk pengembangan ekonomi Indonesia, dan diharapkan dapat menjadi basis penguatan industri Indonesia, terutama industri kecil yang baru tumbuh. Ini juga dapat menjadi acuan bagi menteri dan pimpinan lembaga

pemerintah nonkementerian untuk menetapkan kebijakan sektoral dalam rangka pelaksanaan percepatan dan pembangunan di bidang masing-masing serta acuan pengembangan ditingkat provinsi dan kabupaten terkait (LIPI, 2008).

Salah satu perwujudan misi pemerintah yang dijabarkan dalam Rencana Pembangunan Jangka Menengah Daerah (RPJMD) Pemerintah Kabupaten Bone tahun 
2013-2019 adalah meningkatkan kesejahteraan masyarakat melalui peningkatan kualitas hidup yang layak, bermatabat serta terpenuhinya kebutuhan dasar yaitu pangan,sandang, papan, kesehatan, pendidikan, lapangan pekerjaan, pemberdayaan- masyarakat dan seluruh kekuatan ekonomi daerah terutama pengusaha kecil, menengah, dan koperasi dengan mengembangkan- sistem ekonomi kerakyatan yang bertumpu pada mekanisme pasar yang berkeadilan, berbasis sumberdaya manusia yang produktif, mandiri, maju dan berwawasan lingkungan. Kebijakan tersebut nantinya diarahkan pada upaya penanggulangan kemiskinan daerah dengan tetap mempertimbangkan kemampuan dan keunggulan lokal yang dimiliki oleh masyarakat. Berikut dilampirkan peta administratif Kabupaten Bone:

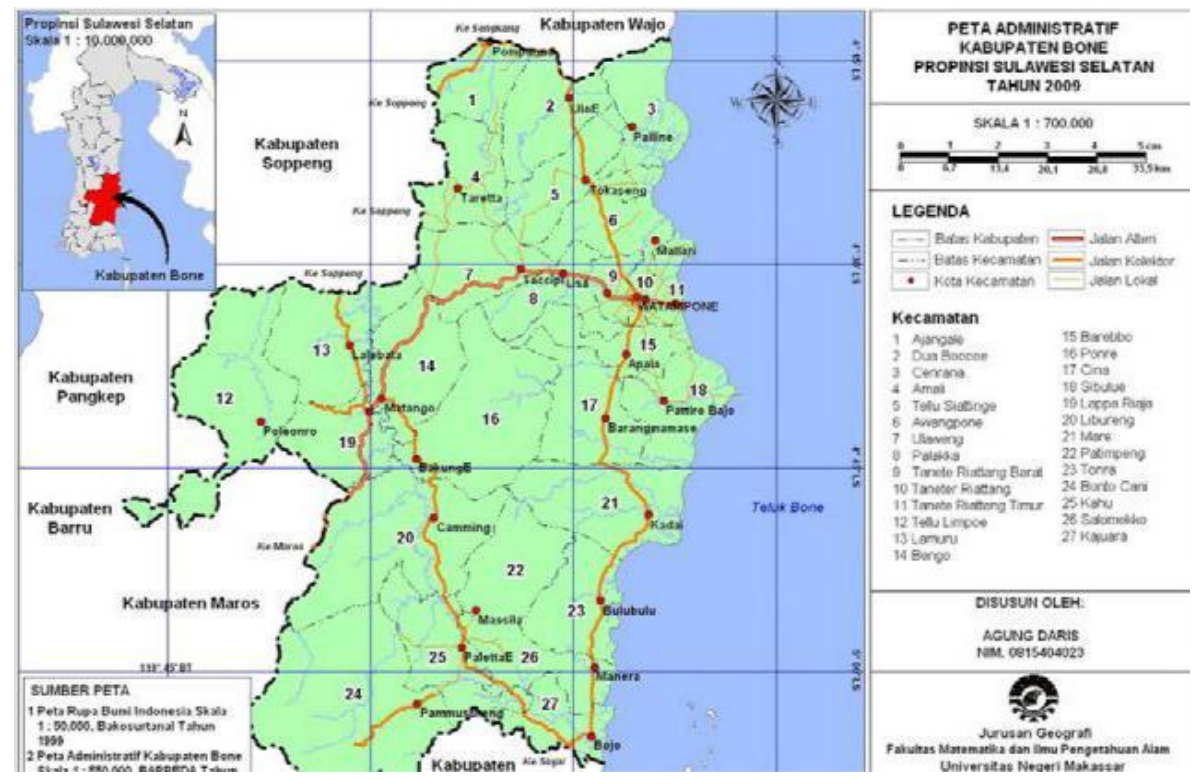

Sumber: Pemerintah Kabupaten Bone, 2017.

Kabupaten Bone merupakan salah satu kabupaten yang terletak di pesisir Timur Provinsi Sulawesi Selatan dan berjarak sekitar 174 km dari kota Makassar.
Luas wilayahnya sekitar $4.559 \mathrm{~km} 2$ atau 9,78 \% dari luas Provinsi Sulawesi Selatan. Wilayah yang besar ini terbagi menjadi 27 kecamatan dan 372 desa/kelurahan 
(Pemerintah Kabupaten Bone, lingkup organisasi bisnis di berbagai 2013). Kabupaten Bone merupakan salah satu Kabupaten di Provinsi Sulawesi Selatan yang memiliki berbagai sentra bisnis Industri Kecil dan Menengah. Berdasarkan data Badan Pusat Statistik (BPS) tahun 2012, sentra industri mengalami peningkatan dari tahun 2008-2012. Pada tahun 2008, sentra industri kecil sebanyak 5 sentra meningkat pada tahun 2012 menjadi Kelompok Usaha Bersama (KUB) dengan total 18 unit. Sampai dengan tahun 2012, KUB yang yang dibina juga mengalami peningkatan. Pada tahun 2008, jumlah KUB yang dibina sebanyak 6 unit meningkat pada tahun 2012 menjadi 17 unit.

Namun demikian, jumlah ini masih relatif kecil apabila dibandingkan dengan jumlah desa yang di seluruh Kabupaten Bone. Hal ini menunjukkan bahwa minat masyarakat untuk berwirausaha masih relatif kecil. Sebagian besar pelaku usaha IKM dan KUB masih memiliki banyak permasalahan antara lain ketrampilan produksi, manajemen pengelolaan usaha, permodalan dan penguasaan ketrampilan. Disebutkan dalam RPJMD tahun 2013-2018 bahwa peluang investasi cukup besar, hal ini ditandai dengan adanya kawasan-kawasan investasi dan wilayah yang semakin bertumbuh pesat serta mudah dijangkau melalui jaringan komunikasi dan teknologi informasi yang semakin meluas dan berperan besar dalam peningkatan $e$ commerce dan bisnis investasi.

\section{Developmental State Sebagai Model Pertumbuhan}

\section{Ekonomi Daerah}

Konsep developmental state merupakan suatu konsep yang memiliki indikator utama, yaitu kuatnya peran pemerintah dalam perekonomian suatu daerah. Peranan tersebut dapat di-iden- tifikasi melalui insentif yang diberikan kepada masyarakat maupun sektor bisnis melalui peraturan administratif, subsidi, proteksi, hingga peninjauan pasar dan kegiatan ekonomi (Woo, 1991). Ciri-ciri model pembangunan developmental state adalah kuat dalam penegakan hukum, bersifat rigid dan tidak mudah mendapatkan intervensi politik. Selain itu, struktur politik sangat mendukung sistem perekonomian dengan adanya hubungan yang erat antara pebisnis dengan pemerintahnya, sehingga tercipta hubungan yang saling menguntungkan diantara keduanya yang bertujuan untuk mencapai kepentingan negara 
baik secara domestik atau di dunia internasional (Weiss, 2000). Untuk Kabupaten Bone, pemerintah daerah melakukan peninjauan lang- sung ke lapangan untuk melihat kondisi dan potensi daerah mana yang harus dikembangkan untuk meningkatkan pembangunan ekonomi daerah.

Disamping itu, pemerintah daerah Kabupaten Bone juga melakukan upaya pendekatan melalui pelatihan yang diberikan oleh penyuluh dari Dinas Perindustrian dan pemberian bantuan modal dan pencarian investor baik lokal maupun asing, untuk memastikan potensi tersebut benar berkembang serta agar dapat melakukan proteksi terhadap industri kecil dan menengah maupun pelaku industri tersebut. Pemerintah memang melakukan intervensi hampir di segala sektor ekonomi, namun terdapat pemisahan tegas antara sistem birokrasi dan kepentingan politik. Sistem politiknya dapat dikatakan bersih, walaupun tidak sepenuhnya karena hubungan antar pebisnis atau sektor swasta dan pemerintah tidak berdasar atas hubungan keluarga sehingga hubungan yang terjadi adalah hubungan yang saling menguntungkan dan tujuan politiknya bisa sejalan dengan kepentingan ekonomi negara (Winanti, 2003). Intervensi pemerintah dalam proses pembangunan yang ditandai dengan kuatnya kontrol pemerintah atas sektor swasta dan dominasinya dalam perumusan kebijakan struktur politiknya.

Salah satu upaya pemerintah untuk meningkatkan perekonomian IKM adalah melalui proses developmental state yang berperan penting dalam pertumbuhan kerjasama dan meningkatnya desentralisasi sistem produksi ekonomi. Otonomi daerah meru- pakan salah satu cara untuk mewujudkan hal tersebut. Pelimpahan hak, wewenang, dan kewajiban yang diberikan oleh pemerintah pusat kepada pemerintah-pemerintah daerah ditiap provinsi dan Kota untuk mengelola daerahnya masing-masing dengan tetap berpegang teguh terhadap UndangUndang Dasar Negara. Dimana hal ini pada akhirnya diharapkan dapat mewujudkan penyelenggaraan pemerintahan yang efektif efisien dan berwibawa demi mewujudkan pemberian pelayanan kepada masyarakat. Munculnya "aktor baru" pemerintah daerah (local goverment) dalam kegiatan ekonomi diharapkan akan dapat 
mempengaruhi pengembangan ekonomi secara nasional.

Selama ini, pertumbuhan dan kontribusi PDRB sektor perdagangan di Kabupaten Bone secara umum mengalami peningkatan yaitu dari kontribusi Rp. 821.678,46 milyar pada tahun 2012, meningkat menjadi Rp. 937.158,81 milyar pada tahun 2013. Sedangkan
Pertumbuhan dan kontribusi PDRB sektor perindustrian juga mengalami peningkatan yaitu dari Rp. 691.259,08 milyar pada tahun 2012 meningkat menjadi Rp. 784.247,77 milyar pada tahun 2013. Berikut tabel indikator pencapain dari sektor perindustrian dan perdagangan di Kabupaten Bone selama kurun waktu 2012-2014:

\begin{tabular}{|c|c|c|c|c|}
\hline M & & \multicolumn{3}{|c|}{ Tahun } \\
\hline 100 & Kegiatan & 2012 & 2013 & 2014 \\
\hline 1 & Unit Usaha (Unit) & 5.803 & 5.816 & 5.829 \\
\hline 2 & Tenaga Kerja & 19.081 & 19.135 & 19.199 \\
\hline 3 & $\begin{array}{l}\text { Nila Investasi (Rp } \\
000)\end{array}$ & 136.079 .461 & 138.760 .461 & 142.089 .461 \\
\hline 4 & $\begin{array}{l}\text { Nilai Produksi (Rp } \\
000)\end{array}$ & 286.959.238 & 292.182 .765 & 293.078 .138 \\
\hline
\end{tabular}

Sumber: RKPD Kab Bone Tahun 2016

Dari tabel di atas terlihat bahwa selama kurun waktu 2012-2014

terjadi pertumbuhan untuk unit usaha rata- rata $0,20 \%$, tenaga kerja $0,24 \%$, nilai investasi $1,85 \%$ dan nilai produksi $1,03 \%$ pada sektor perindustrian memiliki potensi yang besar dan strategis dalam meningkatkan aktifitas ekonomi daerah sekaligus mendorong pemerataan pendapatan yang lebih baik. Kegiatan IKM yang terdapat beberapa wilayah, berperan besar dalam penyerapan tenaga kerja dan pembentukan PDRB. Karena pada dasarnya masyarakat akan lebih banyak berperan sebagai pelaku usaha baik usaha kecil, menengah maupun besar. Kemampuan usaha kecil dan menengah dalam menghadapi krisis perlu mendapat dorongan dan pengarahan terutama dalam meningkatkan kemampuan permodalan, inovasi, kreativitas usaha serta perluasan pasar melalui promosi.

Berdasarkan hal tersebut, pemerintah melakukan pengem- 
bangan lembaga dan asosiasi usaha kecil menengah yang diharapkan mampu menjadi wadah untuk lebih mengembangkan dan saling tukar informasi, pengetahuan dalam rangka meningkatkan usaha dan permodalan. IKM ini perlu mendapatkan dorongan dalam mengembangkan dan meningkatkan kemampuan daya saing pasar bebas dan persaingan global. Misalnya saja, para pelaku industri di sektor rumput laut. Pemerintah Kabupaten Bone mengetahui komoditi ini yang paling banyak diminati, karena tidak membutuhkan modal besar dengan harga yang cukup bersaing, sehingga masih terbuka luas untuk pengembangan dalam rangka memenuhi kebutuhan industri nasional dan pasar dunia. Begitu juga dengan industri udang dan kepiting yang juga menjadi komoditi utama yang diunggulkan, mengingat komoditi ini telah memiliki pangsa pasar khusus di luar negeri (RKPD Kabupaten Bone, 2016).

Dipaparkan pula bahwa Kabupaten Bone merupakan wilayah dengan potensi tambang emas yang besar di Sulawesi Selatan. Pemerintah Provinsi dan Pemerintah Kabupaten sudah mulai menjaga dan mengawasi potensi ini agar dapat diolah menjadi industri yang menjanjikan kehidupan yang layak bagi masyarakat lokal. Upaya tersebut dilakukan dengan meningkatkan kerjasama dengan Australia. Pemanfaatan dan pengelolaan sumber daya alam ini harus dibangun melalui kegiatan industri dengan investasi yang cukup besar, termasuk di dalamnya desain lokasi, survey lapangan dan studi kelayakan baik secara ekonomi maupun sosial. Menurut hasil pengamatan ahli pertambangan Australia, Edward Bernard menyatakan bahwa di kawasan hutan daerah Bone ter- dapat potensi kandungan emas yang besar (Kompas, 27 Oktober 2008). Segala kebijakan dan upaya pembangunan yang telah dilakukan telah menunjukkan hasil yang menggembirakan hal tersebut dapat dilihat dari besarnya nilai PDRB atas dasar harga berlaku tahun 2014 telah mencapai $19.739 .118,2$ juta rupiah. Salah satu manfaat hasil perhitungan PDRB atas dasar harga berlaku yaitu dapat digunakan untuk melihat gambaran struktur perekonomian suatu daerah atau wilayah.

Dalam sektor perikanan dan kelautan, Pemerintah Kabupaten Bone melakukan kerja sama dan kolaborasi kebijakan dengan Badan Pengembangan Sumber Daya 
Manusia Kelautan dan Perikanan (BPSDM KP), Kementerian Kelautan dan Perikanan (KKP). Upaya tersebut berwujud Perjanjian Kerja Sama (PKS) dengan Pemerintah Kabupaten Bone tentang pembangunan dan pengembangansumber daya manusia kelautan dan perikanan (SDM KP) di Kabupaten Bone. Kerja sama ini merupakan wujud dari upaya pengutan beberapa sektor diantaranya meliputi peningkatan kapasitas SDM KP, peningkatan kegiatan pengabdian masyarakat di bidang kelautan dan perikanan, pemanfaatan sarana dan prasarana, serta perluasan informasi dan kesempatan kerja sektor kelautan dan perikanan diharapkan bisa membantu sektor sektor usaha kecil dan menengah. Sebagai upaya pengembangan penerapan strategi developmental state kuatnya peranan pemerintah daerah juga di terapkan melalui kegiatan penyelenggaraan pendidikan, pelatihan, dan penyuluhan bidang kelautan dan perikanan, advokasi dan sosialisasi kebijakan pemerintah di sektor kelautan dan perikanan dilakukan juga guna mendukung industri kecil dan menengah (IKM). Selain itu juga terdapat kerjasama pemanfaatan fasilitas pendukung kegiatan peningkatan kapasitas SDM, serta penciptaan lapangan pekerjaan sektor kelautan dan perikanan di Kabupaten Bone.

Kerjasama strategis sebagai upaya penerapan developmental state diperlukan sinergitas antara Pemerintah Daerah dan Pemerintah Pusat. Kabupaten Bone memiliki potensi kelautan dan perikanan yang sangat besar. Potensi tersebut terlihat secara geografis bahwa Kabupaten Bone memiliki garis pantai yang membentang sepanjang $138 \mathrm{~km}$ dengan luas 101.638 ha. Keuntungan demografis ini memberikan kesempatan kepada Kecamatan atau wilayah yang berada di wilayah pesisir pantai untuk mengembangkan potensi tambak sebesar 15.244 ha. Pengembangan tersebut kini sudah terealisasi sekitar 11.632 ha. Jenis budidaya yang dikembangkan masyarakat pesisir di Kabupaten Bone adalah budidaya rumput laut, udang, bandeng, serta kepiting jenis bakau. Mengenai SDM KP, Kabupaten Bone juga memiliki kelompok masyarakat kelautan dan perikanan sebanyak 625 kelompok yang terdiri dari kelompok IKM nelayan sebanyak 179 Kelompok Usaha Bersama (KUB), pembudidaya ikan sebanyak 287 Kelompok Pembudidaya Ikan (Pokdakan), pengolah dan pemasar sebanyak 77 Kelompok Pengolah dan Pemasar 
(Poklahsar), serta terdapat 59 Kelompok Masyarakat Pengawas (Pokwasmas), dan pembenih ikan sebanyak 6 kelompok. Harapan masyarakat sangat tinggi dengan adanya kerjasama ini, implementasi kerja sama juga diharapkan bisa mendapatkan hasil yang maksimal.

Pemerintah daerah Kabupaten Bone juga melakukan kerjasama dengan pemerintah pusat guna memperkenalkan tiga pabrik gula (PG) di provinsi Sulawesi Selatan, salah satunya di Kabupaten Bone, yaitu PG Bone kepada investor asing. Upaya kerjasama ini dilakukan agar produktivitas produksi gula semakin meningkat. Adapun PG Bone memaparkan bahwa produksi gula PG Bone setiap tahunnya mengalami peningkatan terus menerus. Untuk tahun 2015 mencapai 13.100 Ton. Kemudian naik menjadi 15.200 Ton pada tahun 2016 dan 19 ribu ton tahun 2017. Dalam lawatannya ke PG Bone, Menteri Pertanian Indonesia, Andi Amran Sulaiman menerangkan bahwa pihak investor dari Taiwan tertarik untuk pengembangan pabrik gula di Bone dengan total nilai investasi sebesar 1,6 triliun rupiah (DPMPTSP, 2014). Berdasarkan hasil wawancara dengan Kepala Bidang Industri Dinas Perindustrian Kabupaten
Bone. Melalui perbincangan awal yang dibuka oleh menteri pertanian, juga akan ditindak lanjuti oleh Pemerintah Daerah Kabupaten Bone dan diteruskan ke Dinas Pertanian dan perindustrian untuk menangani hal tersebut dan Memorandum of understanding (MoU) akan dikeluarkan oleh 2 dinas tersebut (Nurhayati, 2015).

Sebanyak Empat lembaga asing yang terdiri dari Asia foundation, Care Internasional, Bakti Ausaid Australia dan Unicef juga akan mengucurkan bantuan dana kepada pemerintah Kabupaten Bone, untuk mewujudkan pembangunan yang ada di Kabupaten Bone khususnya di sektor- sektor usaha kecil masyarakat. Selain dukungan dana, keempat lembaga asing ini juga menawarkan pengawalan dalam mewujudkan visi misi Bupati Bone yang baru dengan penandatanganan kesepakatan $M o U$. Kesepakatan ini dalam rangka memberikan dukungan mewujudkan visi misi dan kegiatan pemerintah daerah. Selain dukungan dalam bidang anggaran, juga terdapatbeberapa kegiatan yang sesuai dengan fokus lembaga itu sendiriseperti permasalahan sosial dan budaya (Badan Perencanaan Pembangunan Daerah, 2013).

Asia Foundation akan menyu- 
sun anggaran yang diarahkankepada kepentingan kaum perempuan dan masyarakat lapis bawah di Kabupaten Bone sedangkan Care Internasional menawarkan per- contohan hasil bumi dan laut seperti usaha IKM rumput laut serta mengundang pemerintah untuk beradaptasi dengan perubahan iklim di Thailand pada bulan Juli 2018.Adapun Unicef, lanjut Irwan, akan membantu pemerintah dalam bidang pendidikan khususnya perencanaan wajib belajar 12 tahun baik dengan dana maupun pen- dampingan lainnya (Suara Bone, 2013).

Melihat berbagai upaya-upaya yang telah dilakukan oleh pemerintah Kabupaten Bone tersebut, hal ini mengindikasikan bahwa terdapat penerapan developmental state yaitu dengan membuka kerjasama dan krankran investasi dari negara lain di beberapa bidang industri kecil menengah, salah satunya dalam bidang budidaya hasil laut dan industri gula yang ada. Pemerintah daerah sebagai aktor, mampu memainkan perannya dengan baik dengan melakukan pengontrolan secara berkala terhadap industri kecil menengah, kemudian mencermati potensi yang bisa dikembangkan dan berhasil mendatangkan investorinvestor asing untuk mem- bantu berkembangnya industri kecil menengah dari berbagai sektor tersebut. Model penerapan developmental state yang dilakukan oleh pemerintah, menjadi contoh pergerakan nyata untuk menjaga perekonomian daerah. Menghadirkan dan melibatkan investor asing untuk meningkatkan sektor industri kecil menengah dapat membantu pemerintah dalam menghadapi berbagai persoalan ekonomi yang terjadi di daerah.

\section{E. Kesimpulan}

Bentuk pergerakan dan strategi dari pemerintah dalam upaya perbaikan pertumbuhan ekonomi adalah dengan melirik sektor Industri Kecil Menengah yang memiliki- peran strategis dalam perekonomian nasional. Dalam hal kemampuan berintegrasi di dalam ekonomi nasional maupun global, sangat jelas bahwa sektor yang masih mengalami kesulitan adalah industri kecil dan menengah. Melihat hal tersebut, salah satu upaya yang dilakukan pemerintah daerah dalam rangka meningkatkan perekonomian melalui sektor Industri Kecil Menengah adalah dengan menjalankan kebijakan developmental state.

Sedikitnya terdapat dua hal yang dapat diambil dari penerapan 
developmental state di Kabupaten Bone, sebagaimana yang dianalisis dalam tulisan ini. Pertama, proses liberalisasi dan ekonomi yang lebih terbuka serta penguatan intervensi pemerintah daerah dalam aktivitas ekonomi, telah banyak membantu meningkatkan pertumbuhan industri kecil menengah. Perubahan paling signifikan terjadi adalah ada- nya peningkatan dan pertumbuhanuntuk unit usaha pada tahun 20102016 sebesar rata- rata $0,20 \%$, peningkatan tenaga kerja $0,24 \%$, dan peningkatan nilai investasi $1,85 \%$ serta nilai produksi $1,03 \%$ pada sektor perindustrian yang mana hal tersebut juga secara langsung akan meningkatkan pertumbuhan ekonomi daerah.

Kedua yaitu munculnya kesadaran dari pemerintah Kabupaten untuk mengoptimalkan potensi daerah dengan meningkatkan kerja sama luar negeri khususnya dengan negaranegara industri maju serta organisasi internasional seperti Asia foundation, Care Internasional, Bakti Ausaid Australia dan Unicef. Kebijakan ini bertujuan untuk meningkatkan pertumbuhan eko- nomi dan daya saing Kabupaten Bone tidak hanya untuk kawasan Sulawesi saja tetapi juga untuk pasar nasional dan internasional. Hal ini menyiratkan liberalisasi tidak hanya dilakukan dalam perdagangan dan industri berskala besar saja tetapi juga industri kecil dan menengah. Pengembangan lembaga dan asosiasi usaha kecil menengah diharapkan mampu menjadi wadah untuk lebih mengembangkan system perekonomian dan mampu menjadi tempat saling tukar informasi, pengetahuan dalam rangka meningkatkan usaha dan permodalan Sehingga Koperasi dan IKM dapat memacu pertumbuhan ekonomi, yang akan memberikan manfaat secara langsung terhadap peningkatan pendapatan masyarakat di Kabupaten Bone.

\section{F. Daftar Pustaka}

Bolesta, Andrzej, 2007, China As

A Developmental State, Montenegrin Journal Of Economics, no 5, pp. 101-120. Dinas Penanaman Modal dan PTSP Provinsi Sulawesi Selatan. 2017. Taiwan Ingin Suntik Rp 1,6 Triliun ke Pabrik Gula. Selengkapnya di <Https:// Dpmptsp.Sulselprov.Go.Id/ Data1- 98-201-Data.Html>, diakses pada 1 Maret 2018.

Fritz, Verena \&Menocal, Alina Rocha, 2007, Developmental States In The New Millennium: Concepts And Challenges For A 
New Aid Agenda, Development Policy Review, 25 (5), pp. 531-552.

https://bone.go.id/2013/04/26/

geografi-dan-iklim/ diakses pada 9 April 2018.

Kasahara, Shigehisa, 2013, The

Asian Developmental State and The Flying Geese Paradigm. Discussion Series. United Nations Conference on Trade and Development.

Kraft, Michael\& Furlong, Scott, 2009, Public Policy: Politics, Analysis and Alternatives, Sage Publishing. Washington D.C.

Kuncoro, Mudrajad. 2007.

Ekonomika Industri Indonesia Menuju Negara Industri Baru 2030? Yogyakarta: Penerbit Andi.

Pangabean, Riana, 2012, Membangun Paradigma Baru dalam Mengembangkan UKM. Infokop. Selengkapnya di www.smecda.com /deputi7/ file_infokop/EDISI\%2025/ pengemb_UKM.pdf>, diakses pada 12 Februari 2018.

Pemerintah Kabupaten Bone, 2013. Geografi Dan Iklim. Selengkapnya di <https://bone. go.id/2013/04/26/geografidan-iklim/ >, diakses pada 19 April 2018.
Pemerintah Kabupaten Bone, 2017. Tinggi Wilayah di Atas Permukaan Laut (DPL) Menurut Kecamatan di Kabupaten Bone. Selengkapnya di https:// bone.go.id/2017/01/03/tinggiwilayah-di-atas-permukaanlaut-dpl-menurut-kecamatandi-kabupaten-bone/ diakses pada 9 April 2018.

Pemerintah Kabupaten Bone. 2013. RPMJ Tahun 20132018. Selengkapnya di $<$ https://sites. google.com/site/pdedokument/ home/download/rpjmd-kabbone - tahun - 2013 - 2018>, diakses pada 12 Maret 2018.

Pemerintah Kabupaten Bone, 2013. Geografi dan Iklim. Selengkapnya di <https://bone. go.id/2013/04/26/geografidan-iklim/>, diakses pada 9 April 2018.

Pemerintah Kabupaten Bone. 2015. Statistik Daerah Tahun 2015, Selengkapnya di <https:// bonebolangokab.bps.go.id/ publication/2015/11/03/ a7489b13b493ebf70366dedb/ statistik-daerah-bone--2015. html>, diakses pada 1 Maret 2018.

Pemerintah Kabupaten Bone. 2016. RKPD Tahun 2016. Selengkapnya di https:// 
bone.go.id/2016/01/26/rkpdkabupaten-bone-tahun-2016/, diakses pada 12 Maret 2018.

Pemerintah Kabupaten Bone. 2017.

Kabupaten Bone Dalam Angka 2016. Selengkapnya di <https:// b o n e.go.id/2017/02/ 21 / kabupaten-bone-dalamangka-tahun-2016/>, diakses pada 12 Maret 2018.

Pemerintah Kabupaten Bone. 2017. Tinggi Wilayah di Atas Permukaan Laut (DPL) Menurut Kecamatan di Kabupaten Bone. Selengkapnya di <https://

bone.go.id/2017/01/03/tinggi-

wilayah-di-atas-permukaanlaut-dpl-menurut-kecamatan-dikabupaten-bone/>, diakses pada 9 April 2018.

Sagena, Uni, 2005, Pergeseran

Mo d e 1 Pe m b a n g u n a n EkonomiDevelopmental State Jepang, Jurnal Sosial Politika, vol. 6 , no. 12, pp. 59-76.

Suara Bone. 2013. Dinas

Pendidikan Kabupaten Bone

Sosialisasi Dana Pendidikan

Gratis. Selengkapnya di Http:// Suarabone.Co.Id/2013/05/ L e $\mathrm{m} \mathrm{b}$ a g a - A s i n g - S i a p Kucurkan-Dana-Untuk.Html>, diakses pada 20 Februari 2018. Suci, Yuli Rahmini, 2017, Perkembangan UMKM (Usaha
Mikro Kecil dan Menengah) di Indonesia. Jurnal Ilmiah Cano Ekonomos. vol. 6, no. 1, pp. 51-58.

The World Bank, 2005, World Development Repor: A Better Climate for Everyone. Oxford University Press. Washington, D.C.

Tun, Sai Khaing Myo, 2011, A Comparative Study Of StateLedDevelopment In Myanmar (1988-2010) And Suharto's Indonesia: An Approach From The Developmental State Theory. Journal of Current Southeast Asian Affairs, no 1, pp. 69-94.

Weiss, Linda \& Thurbon, Elizabeth, 2016, The Developmental State in the Late Twentieth Centur y. Selengkapnya <dihttps://www.researchgate. net/publication/310621129>, diakses pada 12 Februari 2018.

Weiss, Linda, 2000, Developmental State in Transition: Adapting, Dismantling, Innovating, not Normalizing. The Pacific Review, vol. 13, no. 1, pp. 1-21. Wie, Thee Kian, 1994, Industrialisasi di Indonesia. Pustaka LP3S Indonesia, Jakarta

Winanti, Poppy Sulistyaning, 2003. Developmental State 
dan Tantangan Globalisasi:

Pengalaman Korea Selatan,

Jurnal Ilmu Sosial dan Ilmu

Politik, vol. 7, no.2, pp 1-15.

Woo, Meredith Cumings, 1999, The

Developmental State, Cornell

University Press, Ithaca, New

York.

Wawancara:

Andi Siti Nurhayati, Kepala Bidang

Industri Dinas Perindustrian

Kabupaten Bone (Periode

2010-2015) 